\title{
Legal Defects and Perfection of Collective Forest Land Property Right System
}

\author{
Peifeng Huang ${ }^{1,2}$ \\ ${ }^{1}$ College of Economics, Fujian Agriculture and Forestry \\ University \\ Fuzhou 350002 \\ ${ }^{2}$ College of Management, Fujian University of Technology \\ Fuzhou 350118
}

\author{
Heliang Huang ${ }^{1^{*}}$ \\ ${ }^{1}$ College of Economics, Fujian Agriculture and Forestry \\ University \\ Fuzhou 350002
}

\begin{abstract}
Since the promulgation and implementation of Forest Law, China has formulated and implemented a series of forestry laws and regulations to protect the development of collective forest land resources, and has been committed to strengthening the security of collective forest land property rights by formal legal means. However, the subject of collective forest land ownership is not clear, the right to use is not complete, the right to benefit is difficult to achieve and the right to dispose is limited. Therefore, we should further clarify the subject of collective forest land ownership, improve the rights to use collective forest land, establish a reasonable forest land valueadded income distribution mechanism and guide the orderly circulation of forest rights so as to improve the collective forest property rights.
\end{abstract}

Keywords-Collective forest land; Property right system; Legal defects; Perfection of law

\section{INTRODUCTION}

From the point of view of economics, property right is essentially a bundle of rights composed of ownership, use right, income right and disposition right. Economic property right is the reflection of the objective existence of property relations, and must be timely recognized and protected by the form of legal rights and the law. Since the founding of the People's Republic of China, China has promulgated a series of forestryrelated laws, regulations and policies, such as The Forest Law, and the definition of collective forest land property rights has been gradually rationalized and standardized. However, due to the relative backwardness of forestry legislation in China, the relevant laws and regulations for collective forest land property rights are not so in-depth and detailed. Years of policy changes have led to the widespread problems of collective forest land property rights in China such as unclear boundaries, unclear powers, unfair distribution of interests, so that it is unable to meet the principle of legal integrity and clarity of property rights. In addition, with the changes of the times and the development of the society, in the implementation process of collective forest land laws and regulations, some defects are gradually exposed, leading to the lack of legal basis in the practice of forest reform, difficult to adapt to the current social development. Therefore, starting from the basic rights and interests of property rights, This paper theoretically analyzes the property right structure and basic function of collective forest land, discusses the defects in the current legal norms for collective forest land property right, and puts forward some countermeasures and suggestions to perfect the collective forest land property right legal system, in order to provide policy reference for further deepening the collective forest right system reform.

\section{PROPERTY RIGHTS AND INTERESTS}

Any property right contains the subject's powers and interests. Power refers to the power or function of the subject of property right over the property, while interest refers to the effect or benefit obtained by the subject of property right through the exercise of the power of property right. Power and interest are interdependent and indispensable, and there is an inherent unity between them. As far as the subject of property right is concerned, firstly interest is the purpose of the implementation of power, and the purpose of obtaining the right is to obtain the interest. Secondly, the right of property is the prerequisite and basis of the existence of interests, and the right can be beneficial. Thirdly, the interests are the result of the exercise of power. The right can be beneficial. Finally, conversely, interest is the condition that makes a power become the content of property right, and interests is the rightbased. Otherwise, the power cannot constitute property rights and has no practical significance (Shao'an HUANG, 1995). Theoretically speaking, four property rights including ownership, possession, domination and use right should have their own powers and interests. Every subject of property right needs to objectify his will on the object of property right, and transform this will into a specific behavior, and obtain corresponding interests through this volition zed behavior.

Property right structure refers to the arrangement of the constituent elements of property right and its internal rights among different subjects under the specific institutional background. The structure of property right is closely related to the function of property right, and the structure influences the function. The divisibility of property right bundle expands the choice of property right space and property right arrangement (Biliang LUO, 2005), and the aggregation of this behavior and choice can reduce uncertainty, stimulate constraint, optimize 
the allocation of resources and use other functions to reduce costs, improve efficiency and increase investment or output (Zhigang CHEN, 2005). Any bundle of rights in a particular group of property has an internal rights structure, usually with two meanings: The first is what rights it consists of and how they relate to each other; the other is the separation and combination of different rights (Shaoan HUANG, 1995). The "four rights", namely, ownership, possession, domination and use right, are only partitions in the general sense, and the powers and interests for any one of rights can be partitioned with more detail according to the needs. In reality, the splitting degree of property rights and the number of rights shall change with the development of social division of labor. The more developed the social division of labor, the more detailed the splitting of property rights, the more the number of rights, and the more complex the structure of property rights.

\section{ANALYSIS OF LEGAL DEFECT OF COLLECTIVE ForEST LAND PROPERTY RIGHT SYSTEM}

\section{A. The subject of collective forest land ownership is not clearly defined}

The law on forestry property rights has not yet formed a unified legal system, and the relevant legal provisions are also lack of in-depth and detailed elaboration. The subject of collective forestland ownership is regulated by the current law, but there are some differences in the expression of different legal provisions. Constitution and Forest Law simply define the subject of ownership as collective ownership, without further stipulating the specific owners of collective forest land, and no more detailed and clear norms can be found in Forest Law Implementation Regulations. Article 74 of the General Rules of Civil Law regulates that: "The property organized by the collective of the working people belongs to the collective of the working masses. Article 2 of the Land Administration Act also states: The People's Republic of China resorts to a socialist public ownership i.e. an ownership by the whole people and ownerships by collectives, of land. These two regulations define the collective land ownership as the collective of the working masses, but the connotation and nature of the collective land ownership are not defined specifically. Article 8 of the Land Management Law further narrows the scope of ownership subject to "peasant collectives", However, there is still no further stipulation on the way in which individual peasants enjoy collective ownership. Instead, it is stipulated that villagers' groups or committees or rural collective economic organizations should unify their operation and management, which will easily lead to the occurrence of land occupation and rent-seeking behavior. The Property Law enacted in 2007 seeks to change this ambiguity, replace the words "owned collectively by peasants" with the words "owned collectively by members of the collective". Through the implementation of membership rights, it aims to further clarify the ownership of the subject, but at the same time, we should also note that there are still many specific issues to be improved in the provisions of collective ownership and membership rights (Liming WANG, 2012), these are also issues that scholars should pay attention to in the follow-up.

\section{B. Incomplete Rights toUse Collective Forest Land}

The implementation of the household contract responsibility system creates a precedent for granting farmers certain limited rights, and establishes their rights of possession, utilization, income and limited disposition within the contract period (Zhongxing GUO et al., 2012). Therefore, collective forest land use right can also be called collective forestland contractual management right. The Land Management Law of 1986 points out that collective or individual may engage in agricultural, forestry, animal husbandry, fishing and other production activities on the contracted land according to the provisions of the contracted management contract, and at the same time, it is clear that the contracted management right of land is protected by law, and the contracted management right is elevated to legal empowerment. The General Rules of Civil Law further clarify the specific content of the right of contractual management of land in civil law, but in judicial practice, the power of the contractual management right is not complete, and it is not clearly defined as a real right, and it is more like a kind of creditor's right. The promulgation of Property Law defines the contractual management right of forest resources as usufructuary right, so that farmers can not only own, use and dispose of the contracted management right according to their own wishes during the contract period, but also avoid too much restriction and arbitrary withdrawal by the contractor, enhance the defensibility of the contractor when their rights are infringed upon, and provide stronger protection for the legal rights of forest farmers. However, in reality, the collective forestland contractual management right is not stable, and the phenomenon of administratively unified land transfer often appears. The property right nature is limited in China's land system, which is a kind of incomplete property right.

\section{Collective forest land income distribution system is not standardized, and the income right is difficult to realize}

The income distribution system of collective forest dland in China is not standardized, which is mainly embodied in the following aspects: Firstly, the principle of income distribution is not clear. Since the implementation of the household contract responsibility system, China has always been following the distribution principle of the "pay enough to state, keep enough to the collective, and keep the rest for their own", but the principle only determines the state, collective and peasant income distribution order, and does not determine the proportion of income distribution among the three. Secondly, the burden of forest land taxes and fees is heavier. In addition to paying state taxes, farmers also have to bear the responsibility of co-ordination and retention by the township or village-level government. Although in recent years, with the continuous progress of collective forest right reform, agricultural tax has been gradually abolished and some forestry taxes and fees have been gradually cleaned up in some regions, but the existing forestry taxes and fees, apportionment and fines are still numerous, together with fees collected by the local forestry sector, the profits of forest land operators are very small (Chang BI et al., 2010). 
Usufruct is an important power of ownership, which is the right of property owners and users to make rational use of property and obtain certain economic benefits (Liming WANG, 2013). Collective forest land income right is an important property right for farmers, as forestland users, to directly or indirectly put into production and management activities, and obtain certain income according to their own corresponding powers. For a long time before the land contract responsibility system is implemented, the right of land usufruct is not prominent in the power of ownership, and the right of land usufruct is not paid attention to correspondingly (Xinyu TANG et al., 2014). With the popularization of household contract responsibility system, farmers, as the occupiers and users of collective land, enjoy the benefits of land occupation and use. However, the emergence of urban-rural dual structure often leads to the violation of rural collective land ownership, farmers' long-term investment in land cannot get the corresponding compensation, and farmers' land acquisition income rights cannot be fully protected.

\section{The collective forest land disposal right is restricted}

Collective forest land disposal right refers to the right of collective economic organizations or farmers to dispose collective forestland property according to law, including the right of purchase and sale of collective forestland property, mortgage, lease, bestowal, inheritance and other secondary rights. China's law clearly prohibits any unit or individual from illegally transferring land in the form of sale or encroachment, but there are still some words such as "disposition", "transfer", "disposal", "lease" and so on in the current relevant policy documents. Document No. 1 of the Central Committee of the Communist Party of China (CPC) in 1984 pointed out that, farmers can find and negotiate the object of land subcontracting. The Decision on Accelerating Forestry Development, issued by the Central State Council in 2003, also explicitly encourages the rational transfer of the right to use forests, trees and forest lands. Obviously, it is unscientific and unreasonable to negate the collective land disposal right. After the promulgation of the Property Law, the collective land disposal right has been recognized by the law and has been elevated to the legal empowerment. According to Article 39 of the Property Law, the actual disposition right only belongs to the owner of the proprietorship. As a kind of usufructuary right, the farmers' collective forest land contractual management right does not have the actual disposition right, but only enjoys certain legal disposition right. In addition, the mortgage of collective forestland contractual management right is also confirmed in relevant policy documents. However, it is not involved in the current laws and regulations except for the Forest Law, which has not been elaborated in detail, and to some extent, it also reflects the relative lagging of the legal design. The Law on Land Management clearly states that: "Land use rights owned by the state and collectives may be transferred according to law. "But at the same time: "Land use rights owned by peasant collectives may not be transferred, assigned or leased for nonagricultural construction. "The hidden meaning of these legal provisions is that the rural collective land use right cannot directly enter the first-class land market, but must be leased by the state or expropriated as state-owned land before it can enter the land exchange market, and the state basically controls the dominant right and usufruct right of collective land transfer (Biliang LUO, 2013).

\section{COUNTERMEASURES AND SUGGESTIONS ON IMPROVING THE LEGAL SYSTEM OF COLLECTIVE FOREST LAND PROPERTY RIGHTS}

\section{A. Earnestly promote the issuance of collective forest land rights certificates, and further clarify the subject of collective forest land ownership.}

In economics, property right is a kind of behavior relation that the property right subject exercises the property right function according to own will. The property right subject exercises the property power and the function, which is the basis and the safeguard for the subject to obtain the interests. If collective forest property right lacks clear subjects, it is very easy to lead to the virtual property right subject, which may avoid them to effectively enjoy the rights of collective forest ownership, easily make related organizations or personnel for rent-seeking, encroachment on forest land and other phenomena, result in unnecessary property rights disputes, and cannot make the property rights trade smoothly, and be not conducive to the protection and development of collective forests in China. Therefore, in the future, we should further deepen the reform of collective forest right system, effectively promote the collective forest land right certificate issuance work, strive to achieve full coverage of the certificate issuance work, and further clarify the ownership subject through the implementation of the Property Law, to avoid the nonfunctioning of collective forest ownership in fact.

\section{B. Perfect the right to use collective forest land and stabilize the contractual management relationship of collective forest land.}

The new round of collective forest right system reform puts the contractual management right of collective forest land into the hands of farmers of the collective economic organization, so it establishes the dominant position of farmers in collective forest land contractual management. Although the ownership and use right of forest land are separated nominally, the boundary between them and their respective responsibilities and rights are not clearly defined in law, which easily leads to the infringement upon farmers' right to use forest land. Therefore, we should fully understand the connotation of forest land contractual management right, and clarify the legal relationship between the contractual right and the management right, comb the "separation of the three rights" policy with legal language to ensure the consistency between the economic and legal logic of the forestland contractual right and the management right, regulate the collective forest land contractual management right according to the theory of usufructuary right, and provide legal support for further deepening the reform of collective forest land right system. 


\section{Establish a reasonable distribution mechanism of the value-added income of forest land to ensure that peasant households enjoy sufficient income rights.}

Property Law stipulates that the subject of ownership has the right to benefit from his real estate according to law. Collective forest land belongs to real estate, so the subject of collective forest land ownership should enjoy the right to obtain collective income according to law. At present, there is no clear legal definition of the concept of "collective" in China, and the boundaries between the levels of "collective" are not clear, causing that when the rights and interests of the subject of ownership are infringed, it is not clear who will claim the rights. Therefore, it is necessary to establish and improve the collective forest land value-added income distribution mechanism, give consideration to the interests of the state, collective and individual, and reasonably improve the individual income of farmers; It is necessary to clearly define the category of public interest, improve the standard of collection and compensation, and effectively protect the farmers' complete right to income.

\section{Standardize the transfer system of forest rights and implement the right to dispose forest land}

Collective forest land disposal right refers to the right of the subject of property right behavior to dispose the forest land in fact or in law and decide its use. It is the manifestation of collective forest land ownership operation, including sale, bestowal, lease, mortgage, inheritance and other rights at a lower level. However, although the rural collective forest land property rights belong to the rural collective ownership, but the collective has no right to trade and dispose, that is, the collective forest land disposal right cannot be exercised in the collective organization. Therefore, in the future, we should give full play to the rural land contractual management rights, forest rights transfer service platform in county and township, support open market transactions, guide the healthy development of forest land property rights transfer market. In order to provide more space for the development of forestry, it is necessary to implement the mortgage right of collective forest land and modify the relevant clauses that limit the mortgage of forest right.

\section{CONCLUSION}

At present, China has basically formed a relatively complete forest legal system headed by the Forest Law, and has formulated a series of legal provisions on the power norms of collective forest land property rights subject and the definition of property rights. The ownership of collective forest land property rights in China is basically clear, and the definition of property right powers and interests is basically complete in law. However, from the actual situation of collective forestland property rights, the relevant legal provisions in the property rights subject, the limits of power and other aspects are not clear and specific, the relevant policy provisions and implementation and legal norms are still inconsistent, which is extremely easy to cause unnecessary forest rights disputes. Moreover, due to the lagging and fragmentation of the development of forestry laws and regulations in China, the legal provisions on forest rights in collective forest reform are not completely consistent, which leads to certain conflicts between the laws and policies of collective forest land, and brings many legal obstacles to the reform of collective forest rights system. Therefore, in the future, we should fully understand the essence of the property law, so as to amend and improve the current forestry legal system. Reform and innovation of forestry legal system has become one of the important tasks of collective forest right system reform.

\section{ACKNOWLEDGMENT}

*.Foundation project: Research on Improving the Rural Collective Forest Right System Reform under the Background of Deepening the Reform in All-round Way (No. 16ZDA024), a Major Bidding Project of National Social Science Foundation of China; Youth Fund for Humanities and Social Sciences Research of the Ministry of Education "Research on Ascertaining the Rights of Forest Land, Security of Property Rights and Transfer of Forest Land" (No. 18YJC790055)

About the author: Peifeng HUANG (1982- ), male, associate professor, doctoral candidate, researching forest property rights and institutions.

Corresponding author: Heliang HUANG (1965- ), male, professor, doctoral supervisor, researching forest property rights and institutions.

\section{REFERENCES}

[1] Shaoan HUANG. Introduction to Property Rights Economics [M] Shandong People's Publishing House, 1995.

[2] Biliang LUO. New Institutional Economics [M]. Taiyuan: Shanxi Economic Publishing House, 2005.

[3] Zhigang CHEN. Farmland Property Right Structure and Agricultural Performance--An Empirical Study on China in Transition Period [D]. Nanjing Agricultural University, 2005.

[4] Liming WANG, Youjun ZHOU. On the Perfection of Rural Land Rights System in China [J]. China Law Science, 2012 (1): 45-54.

[5] Zhongxing GUO, Zhiwen LUO. Evolution of Farmland Property Rights: Integration, Completeness and Personalization [J]. Population, Resources and Environment of China, 2012 (10): 123-130.

[6] Chang BI, Yongfu CHEN. Analysis on Legal Issues of Forest Farmers' Rights and Interests Protection from the Perspective of the Right to Development [J]. Forestry Economics, 2010, (2): 146-150.

[7] Liming WANG. Research on Property Law [M]. Beijing: China Renmin University Press, 2013.

[8] Xinyu TANG, Yarong LIANG. Retrospect and Prospect of the Evolution of Farmers' Collective Land Income Right in China [J]. Agricultural Economics, 2014 (5): 61-67.

[9] Biliang LUO. Property Right Intensity and Farmers' Land Rights and Interests: An Introduction [J]. Journal of Huazhong Agricultural University (Social Sciences Edition), 2013 (5): 1-6. 